\title{
5. Sınıf Türkçe Ders Kitabındaki Metinlerin İlettiği Değerler Açısından İncelenmesi
}

\section{The Investigation of the Texts in Fifth Grade Turkish Course Book in Aspect of the Values It Conducts}

\section{Gülçin ÇIRAK ${ }^{*}$ Döndü Bahar SAHİN** Elif Bengi ÖZBERK ${ }^{* * *}$ Hayriye Merve ERİş****}

Öz: Bu araştırmanın amacı, ortaokul 5. sınıf Türkçe ders kitabındaki metinlerin ve şiirlerin öğrencilere aktardığı değerleri içerik analizi yöntemiyle incelemektir. Araştırmanın örneklemini, Milli Eğitim Bakanlığ1 (MEB) ortaokul 5. sınıf Türkçe ders kitabındaki temalarda yer alan 29 metin ve 11 şiir oluşturmaktadır. Bu kategorilerin oluşturulmasında Türkçe ders kitabının öğrencilere kazandırması gereken değerlere ve kategorilerin oluşturulmasında uyulması gereken teknik özelliklere dikkat edilmiştir. Bu araştırmada analiz tekniği olarak duygusal yön ve anlamsal (semantik) içerik analizi kullanılmıştır. Yüzdeler esas alındığında metinlerde ele alınan değer kategorilerinin içerisinde ele alınan 2173 cümlede vatanseverlik değerini içeren cümlelerin birinci sırada olduğu, bunu sırasıyla denetim ve duyarlılık, bilimsel bilgi, yaratıcılık, bilimsellik, eğlence, sevgi, çalışkanlık, sorumluluk, saygı, estetik, sağlık, bağımsızlık ve dinsellik değerini içeren cümlelerin izlediği sonucuna ulaşılmıştır. Her bir cümle bu ölçütlere göre incelendikten sonra frekans ve yüzdeleri bulunmuş ve içerdiği değerler bazında tablolaştırılmıştır. Duygusal yön analizi sonuçlarına göre ele alınan 15 kategoride de pozitif anlam yüklü cümlelerin çoğunlukta olduğu saptanmıştır.

Anahtar sözcükler: Değerler, İçerik Analizi, Duygusal Yön Analizi, Beşinci Sınıf, Türkçe Ders Kitabı

Abstract: The purpose of this research is to investigate the literary text and poets of $5^{\text {th }}$ grade Turkish coursebook with regards to the values transferred to students thorough using the content analysis method. The research sample consisted of 29 literary texts and 11 poets on the themes of Milli Eğitim Bakanlığ1 (Turkish Ministry of Education). While developing categories, the researchers regard to Turkish gradebooks acquitions and technical details. In this research the model for emotional milestones and the context analysis method were used. In literary texts 2173 sentence containing patriotism, has the largest frequency, and is followed by supervision, sensitivity, respect, esthetic, health, independence and religiosity were found. After the all sentences were categorized, the frequencies and percentages have been calculated and summarized in the table. According to model for emotional milestones, positive sentences are predominant amongst the 15 categories.

Keywords: Values, Context Analysis, Model for Emotional Milestones, Fifth Grade, Turkish Course Book

\footnotetext{
* Uzman, PhD., Ankara Üniversitesi, Eğitim Bilimleri Enstitüsü, Ankara, cirakgulcin@gmail.com

** Öğr. Gör., Recep Tayyip Erdoğan Üniversitesi, Eğitim Fakültesi, Rize, bahar.sahin@erdogan.edu.tr

*** Uzman, PhD., Ankara Üniversitesi, Eğitim Bilimleri Enstitüsü, Ankara, ebengiunsal@yahoo.com

**** Araş. Gör., Düzce Üniversitesi, Eğitim Fakültesi, Eğitim Bilimleri Bölümü, Düzce, merveeris87@gmail.com
} 


\section{Giriş}

Her toplum, üyeleri arasındaki birliğini koruyarak, devamlılığını sağlamak için değerlerini yeni yetişen kuşaklara kazandırmak ister. Dürüstlük, sevgi, saygı, hoşgörü, sorumluluk, özdenetim, merhamet, çalışkanlık, cesaret gibi değerleri kazanan bireylerin kararlarını ve seçimlerini daha iyi kontrol edebileceği ve daha az olumsuz davranışlar içine girebileceği söylenebilir. Okul, iyi vatandaşlar yetiştirmek ve bu yolla toplumun devamlılığını sağlamak için, bireylere, toplumun ve insanlığın ortak malı durumuna gelen değerleri kazandırmada etkili bir aracı kurumdur.

Eğitim-öğretim faaliyetlerinin etkili bir şekilde yürütülmesi, kalıcı olması, öğrencinin güdülenmesi için öğretim materyallerine ihtiyaç duyulmaktadır (Kılıç, \& Seven, 2002, 123; Ünlüer, \& Yaşar, 2012, 43-57). Öğretim sürecinde kullanılan materyaller çok çeşitli olmakla birlikte öğrenci ve öğretmen tarafindan en yaygın ve ortak kullanılan ders kitaplarıdır (Ulu Kalın, \& Topkaya, 2009). Günümüzde ders kitaplarının sınıf içindeki yeri hâlâ önemini sürdürmekte olup, öğretmenler birçok etkinliği kitap ile yürütmektedirler. Çoğu öğretmen, öğretim programlarına hiç bakmadan öğrenme-öğretme etkinliklerine ilişkin düzenlemeleri ders kitaplarına göre yapmaktadır. Bundan dolayı ders kitaplarının önemi daha da artmaktadır. Gerçekten bir dersin amacına ulaşmasında ders kitabının önemli katkısı yadsınamaz. Ders kitapları, bir yandan öğrencilerin neler öğreneceklerini belirlerken, diğer taraftan öğretmenlerin öğreteceklerini de etkileyen kaynaklardır. Buna karşın belki de en fazla eleştirilen eğitim araçlarıdır. Kuşkusuz, ders kitaplarının hazırlanmasında her bir boyutun (programa uygunluğu, dil ve anlatım özellikleri, görsel düzen ve ölçme değerlendirme) ayrı bir önemi vardır (Küçükahmet, 2003, 35-36). Ders kitapları, MEB tarafından hazırlanan ders kitapları hazırlama yönetmeliğinde belirtilen ölçütlere göre hazırlanmış olsa da öğretim materyallerinden istenilen düzeyde faydalanabilmek için onu kullananların belli niteliklere sahip olması germektedir (Akdeniz, et alii, 2011).

Türkçe dersi Türkiye'de ilköğretim birinci sınıftan başlayarak üniversite öğrenimi de dâhil olmak üzere öğrencilere tüm öğrenim hayatları boyunca okutulan bir derstir. Bu kadar uzun süreli okutulması, dilin hem ulusun hem de kültürün simgesi olması ve öğrencilerin bu unsurların farkında olması amacını taşımasından kaynaklanır. Ana dili öğrenme süreci önce kamu alanında gelişigüzel kültürleme yoluyla olmakta; bunu okullarda kasıtlı kültürleme yolu izlemektedir. Okullarda yer alan kasıtlı kültürleme yoluyla ana dili öğretimi dilin kurallarını ve doğru kullanımını bireylere kazandırmayı amaçlamaktadır (Demirel, 1996, 59). Öğrenci ilkokul çağına kadar dili ve kültürü ailesi ve yakın çevresinden az çok edinir; ancak bu öğelerin sistemli ve amaçlı öğretilmesi okula başlamayla birlikte özellikle Türkçe dersleriyle gerçekleştirilir.

Türkçe dersi; doğru ve güzel okumayı / yazmayı, etkili dinlemeyi, dil bilgisi kurallarını uygulatmayı ya da etkili konuşmayı amaçlamanın yanında; bireyin millî, ahlaki, sosyal ve evrensel değerlere sahip olmasını da amaçlar. Türkçe dersinin değerlerle ilgili amaçlarını gerçekleştirmede duyuşsal eğitim devreye girer. Duyuşsal eğitimin içinde insana kazandırılmak istenen duygular, tercihler, değerler, ahlaki kurallar, istek ve arzular, güdüler, yönelimler, duygulanışlar (Bacanl1, 1999) yer almaktadır. Diğer eğitim alanlarında olduğu gibi duyuşsal eğitimde hedeflenen amaçlara ulaşmanın temelinde, doğru materyalin doğru zamanda ve doğru yöntemle öğrenciye verilmesi esastır. Kullanılacak bu materyallerin en başında da ders kitapları gelmektedir.

Ders kitapları, eğitimin vazgeçilmez bir parçasıdır ve öğrencilerin dil, zihin gelişimlerini sağlamanın yanı sıra kişiliklerinin de oluşmasında önemli bir rol üstlenir. Anadil öğretiminde okuma, dinleme, konuşma, yazma, görsel okuma ve görsel sunu becerilerindeki başarı, büyük oranda ders kitaplarının kalitesi ile doğru orantılıdır. Anadil öğretiminde ve değerlerin aktarımında Türkçe ders kitaplarında yer alan metinler ön plana çıkmaktadır. 
Bir toplumun fertlerini birbirine bağlayan ve toplumun devamını sağlayan unsurların başında değerler gelmektedir. Değerler, sosyal dayanışma oluşturarak toplumda uyulması gereken ortak davranış kalıplarını belirlemektedir. Çocukların değerleri kazanma süreci aile ile başlamakta okul ile devam etmektedir. Nitekim Lovat, \& Clement'e (2008, 273-285) göre değerler eğitimi, çocuğun yetenekleri ve olanaklarına odaklandığından nitelikli öğretimin gerçekleşmesine de olanak sağlar.

Değer, belirli bir durumu bir diğerine tercih etme eğilimi olarak tanımlanmaktadır. Değerler, davranışlara kaynaklık eden ve onları yargılamaya yarayan anlayışlardır. Değerler, ayrıca bireylerin neyi önemli gördüklerini tanımlayarak istekleri, tercihleri, arzu edilen ve edilmeyen durumları gösterir (Erden, 2003, 319). Değerler, toplumun tarihi birikimi ile ortaya çıkan; toplumun tamamı tarafından kabul gören; toplumun varlık, birlik ve devamının sebebi olarak görülen; tasvip ve teşvik gören; korunan kabulleniş ve inanışlardır. Değerler ve normlar, kültürel kimliğin şekillenmesinde etkili olan kültür unsurlarıdır (Tural, 1992, 109). Dolayısıyla değer "kültür" kavramıyla da yakından ilgilidir.

Değerler; genelde inanılan, arzu edilen ve davranışlar için bir ölçek olarak kullanılan olgulardır. İlk defa Znaniecki tarafindan sosyal bilimlere kazandırılan değer kavramı, Latince "klymetli olmak" veya "güçlü olmak" anlamlarına gelen "valere" kökünden türetilmiştir (Bilgin, 1995, 20). Değer kavramı "bir şeyin arzu edilebilir veya edilemez olduğu hakkındaki inanç" (Güngör, 1993, 18) olarak tanımlanmaktadır. Aydın'ın $(2004,64)$ Theodorson'dan aktardığına göre, değer sosyal olguların önemliliği üzerindeki değerlendirmede, özel eylemleri ve amaçları yargılamada temel ölçü sağlayan ve bir grubun üyelerinin güçlü duygusal bağlarıyla oluşmuş soyut, genelleştirilmiş davranış prensipleridir.

Öğrenciler, değerleri oluşturma konusunda okulun içindeki ve dışındaki kaynakların (öğretmenler, ebeveynler ve medya gibi) etkisi altındadır (Harris, 1991, 32). Okullar, değere dayalı örgütler arasında yer alır ve insan ilişkilerinin önemini vurgulayan değerlerin öncelikli olarak okullarda algılanması beklenir (Sağnak, 2007, 715-726). Lazerson, Mclaughlin, McPherson et alii'e (1985) göre okulun güdülemesi gereken en önemli değerler şunlardır: Dürüstlük, özgürlük, saygı, mutluluk, sorumluluk, sevgi, barış, haksızlık, eşitlik, cesaret, merhamet, hoşgörü, estetik değerler, bilgelik, adalet, mükemmellik, sabır, gurur, insanlık, dini değerler, çevreyi korumak, içtenlik, ruhsal değerler, ekonomik değerler, empati, rekabet, diğerlerine hizmet ve demokratik değerler. Fayda’ya göre (2005), örnek insanda bulunması gereken vasıflar ise vicdan, adalet, vefa, akı1, irade, şahsiyet, karakter, inanç, edep, haya, sabır, hoşgörü, rıza, muhakeme, azim ve çalışkanlıktır.

Çocuk, kültür değerlerini sadece örgün eğitim ve ilişkiler yoluyla değil, aynı zamanda atasözleri, deyimler, şarkılar, tekerlemeler gibi farklı kaynaklardan gelen iletilerle de öğrenir. Çocuğun karşılaştı̆̆ değişik iletiler arasında özellikle dil ve edebiyat farklı bir yere sahiptir (Baymur, 1996, 23). Genel olarak sanatın amacı, yaşamı kolaylaştırmak olduğu gibi edebi eserler de insanın iç dünyasını yumuşatır. İnsan sevgisiyle, yurt sevgisiyle, yaşama sevgisiyle, daha nice sevgilerle yumuşatır. İyilik, dostluk, hoşgörü, bağışlama, dayanışma, çalışkanlık, dürüstlük gibi insana özgü temel duyguları geliştirip pekiştirir (Kavcar, 1999, 6). Diğer yandan yazı dilinin kalıcı olmasından dolayı yazılı edebi eserler, ait oldukları toplumlara özgü değerleri gelecek nesillere taşır.

Derste okunan metinler böylece öğrenciye temel dil becerilerini kazandırmada ve değerlerin gelecek nesillere devredilmesini, aşılanmasını sağlamada ilk sırayı almaktadır. Hatta okuma alışkanlığını edindirmenin de ilk basamağında ders kitabı yer alıyor gibi görünmektedir. Eğer metinler hedef kitlenin seviyesinde, ilgi çekici, zevkli ise öğrencilerde okuma isteği ve sevgisi 
oluşacaktır. Dolayısıyla, Türkçe dersinde kullanılacak metinler rastgele seçilemez. Kullanılacak metinler dil, üslup, yazım yönünden bazı özellikleri içermelidir. Ders kitabı hazırlayanların metin seçiminde titiz davranması gerekir.

Ortaokul Türkçe Dersi 5. sınıf öğretim programında, değerlerin öğretimi ile ilgili bilgi ya da Türkçe dersinde verilmesi gereken değerlere ilişkin bir açıklamaya yer verilmemiştir. Programda ilk önce Türk Millî Eğitim'inin Temel Amaçları (MEB 2013:1) belirtilmiştir. Üç maddelik bu amaçlara bakıldığında insani, ahlaki, millî, manevi ve kültürel değerlerin Türk milletinin her bir ferdine aktarılmasının hedeflendiği anlaşılmaktadır. İnsani, ahlaki, milli, manevi ve kültürel değerleri kapsayan bu amaçlar geneli ifade etmek açısından uygundur. Türk Millî Eğitimi'nin temel amaçlarından sonra Türkçe öğretimi programının temel yaklaşımı (MEB 2013, 3) “Türkçe Dersi Öğretim Programı'yla dinlediklerini, izlediklerini ve okuduklarını anlayan; duygu, düşünce ve hayallerini anlatan; eleştirel ve yaratıcı düşünen, sorumluluk üstlenen, girişimci, çevresiyle uyumlu, olay, durum ve bilgileri kendi birikimlerinden hareketle araştırma, sorgulama, eleştirme ve yorumlamayı alışkanlık hâline getiren, estetik zevk kazanmış ve millî değerlere duyarlı bireyler yetiştirilmesi amaçlanmıştır" ş̧eklinde ifade edilmiştir. Programın temel yaklaşımında millî değerlerin aktarımı yer almıştır, fakat örtük bir şekilde bırakılmıştır. Değerler, sistemli bir şekilde verilmemiş, ayrı başlık altında ele alınmamıştır. Bu nedenle beşinci sınıf Türkçe ders kitabında yer alan metinlerin hangi değerleri ilettiğinin ve bu değerlerin dağılımlarının belirlenmesine gerek duyulmuştur.

\section{Amaç}

$\mathrm{Bu}$ araştırmanın amacı, ortaokul 5. sınıf Türkçe ders kitabındaki metinleri ve şiirleri öğrencilere ilettiği değerler açısından içerik analizi yöntemiyle incelemektir.

\section{Önem}

$\mathrm{Bu}$ araştırma,

1. Türkçe ders kitaplarındaki metinlerin ve şiirlerin aktarılan değerler bakımından genel görünüşünün ortaya çıkarılması,

2. Türkçe ders kitaplarına metin ve şiir seçmenin önemine dikkat çekilmesi,

3. Türkçe dersinde aktarılan değerler ile ilgili bilimsel bilgi sağlaması,

4. Türkçe ders kitabına yönelik içerik analizi örneği olması açısından önemli görülmüştür.

\section{Sinırlılık}

1. Çalışma, MEB 5. sınıf Türkçe ders kitabındaki temalarda yer alan 29 metin ve 11 şiir ile sinırlidir.

2. Araştırmada kategoriler araştırmacılar tarafından belirlenmiştir. Belirlenen kategoriler vatanseverlik, duyarlılık, sorumluluk, sevgi, sağl1k, dürüstlük, bilimsellik, bağımsızlık, çalışkanlık, saygı, estetik, denetim, dinsellik, yaratıcılık, bilimsel bilgi ve eğlencedir. Metinlerin analizinde değerler verilen kategoriler ve özel alt alanları çerçevesinde incelenmiştir.

\section{Sayıltılar}

1. Kategoriler açık seçik belirlendiğinden ve araştırma dört araştırmacı tarafından yürütüldüğünden, amaç ve araçlar arasında uygunluk olduğundan geçerli ve güvenilirdir. 


\section{Yöntem}

\section{Araştırma Modeli}

İçerik analizi, Tavşancıl ve Aslan (2001)'a göre sözel veya yazılı diğer materyallerin içerdiği mesajı, anlam veya dilbilgisi açısından sistematik, nesnel olarak sınıflandırma, sayısallaştırma ve çıkarımda bulanarak sosyal gerçeği araştıran bilimsel bir yaklaşımdır. Bir başka tanıma göre içerik analizi bir okuma metninin, görüntülerin ya da sembolik bir nesnenin araştırmacının ya da kullanıcının bakış açısını gerektirmeksizin sistemleştirilmesi ve metinlerin tekrarlanabilir ve geçerli yorumlar yapılmasında kullanılan bir araştırma tekniğidir (Krippendorff, 2004, 411-433). Bu araştırmada ortaokul 5. sınıf Türkçe ders kitabının öğrencilere ilettiği değerler incelenmiştir, bu nedenle içerik analizi tekniklerinden hem duygusal yön analizi hem de semantik analiz kullanılmıştır.

\section{Evren ve Örneklem}

$\mathrm{Bu}$ araştırmanın evrenini, Milli Eğitim Bakanlığı (MEB) tarafından hazırlanmış ve basılmış ve Talim Terbiye Kurulu'nca onaylanmış Türkçe ders kitapları, araştırmanın örneklemini, Milli Eğitim Bakanlığı ortaokul 5. sınıf Türkçe ders kitabındaki temalarda yer alan 29 metin ve 11 şiir oluşturmaktadır.

\section{Verilerin Toplanması}

Araştırma sorusunun sistematik bir analiz yöntemine dönüşmesindeki en önemli adımlarından biri kategori sisteminin oluşturulmasıdır (Gökçe, 2006, 18). Bunun için mesajın birtakım kategorilere bölünmesi ve belirli kodlama ya da kayıt birimlerinin belirlenmesi gerekmektedir (Tavşanc1l, \& Aslan, 2001, 90). Araştırmada çözümleme birimi olarak temalar alınmıştır. Araştırmacı başlangıcı kuramsal temeller doğrultusunda yapıp hazır bir kategori sistemi ile kodlamaya başlasa da materyaller incelendikçe bu kodlama sistemi üzerinde değişikliklere gidilebilir. $\mathrm{Bu}$ durumda tümevarım ve tümdengelim birlikte kullanılmış olur (Bilgin, 2006; Gökçe, 2006, 18). Türkçe ders kitabı incelenirken kategorilerde MEB'in belirlediği değerlerden yararlanılmış, bazıları ise araştırmacılar tarafindan kitap incelenirken eklenmiştir. Kategoriler homojen olmalı, kendi içinde birbirine benzeyen öğeler içermelidir. Ayırt edici ve farklılaştırıcı olmalı yani kategori kapsamları birbiri ile örtüşmemelidir. Bir kategoriye giren birim başka bir kategoriye kesinlikle girmemelidir. Bütünsel ve kapsamlı olmalı yani kayıt edilen tüm birimleri kapsayacak nitelikte olmalı, kodlanamayan birim kalmamalıdır. Nesnel olmalı bilimsellikten uzaklaşmamalıdır (Gökçe, 2006; Büyüköztürk, et alii, 2010; Yıldırım, \& Şimşek, 2011). Bu kategorilerin oluşturulmasında Türkçe ders kitabının öğrencilere kazandırması gereken ve kategorilerin oluşturulmasında dikkat edilmesi gereken teknik özelliklere dikkat edilmiştir.

Her bir metindeki ve şiirdeki cümleler tek tek incelenerek belirlenen kategorilere yerleştirilmiştir. Birinci kategoride (vatanseverlik) 7; ikinci kategoride (duyarlılık) 7; üçüncü kategoride (sorumluluk) 4; dördüncü kategoride (sevgi) 5; beşinci kategoride (sağlık) 2; altınc1 kategoride (dürüstlük) 0; yedinci kategoride (bilimsellik) 6; sekizinci kategoride (bağımsızlık) 4; dokuzuncu kategoride (çalışkanlık) 2; onuncu kategoride (saygı) 6; on birinci kategoride (estetik) 2; on ikinci kategoride (denetim) alt1; on üçüncü kategoride (dinsellik) 1; on dördüncü kategoride (yaratıcılık) 3; on beşinci kategoride (bilimsel bilgi) 0 ; on altıncı kategoride (eğlence) 2 özel alt alan bulunmaktadır. Bunlar dışında kategorilere girmeyen cümleler dolgu cümleleri olarak değerlendirilmiştir. Eğer cümle pozitif ise "1" ile negatif ise "5", müphem ise "7", karışık ise " 3 " rakamı ile şifrelenmiştir. Cümleler kategoriye yerleştirilirken birinci rakam pozitif, negatif, müphem, karışık yani duygusal yönünü; ikinci rakam kategoriyi; üçüncü rakam ise özel alt 
alanı belirtmek için kullanılmıştır. Cümle kategori ve özel alt alana girmiyor ise "0" ile şifrelenmiştir.

\section{Verilerin Çözümlenmesi}

$\mathrm{Bu}$ araştırmada analiz tekniği olarak duygusal yön ve anlamsal (semantik) içerik analizi kullanılmıştır. Şiirlerde her dize bir cümle kabul edilmiştir. Her bir cümle bu ölçütlere göre incelendikten sonra frekans ve yüzdeleri bulunmuş ve içerdiği mesajlar bazında tablolaştırılmıştır. Güvenirliği sağlamak üzere metinler ve şiirler belirli zamanda araştırmacılar tarafından kodlanmıştır. Daha sonra araştırmacılar arasında çapraz kontrol yapılmıştır ve her birinden elde edilen sonuçlar arasındaki korelasyon katsayısı hesaplanmıştır. Güvenirliğin test edilmesi için Miles ve Huberman (1994; akt. Tavşancıl, \& Aslan, 2001) tarafından aşağıdaki formül önerilmektedir.

Güvenirlik = uzlaşma sayısı/uzlaşma+uzlaşmama sayısı

Kodlayıcılar arasındaki uygunluğu test etmeye yönelik elde edilen eşitliğin \%70'den daha yüksek bir sonuç vermesi beklenir. Bu araştırmada;

Güvenirlik $=1582 /(1582+591)=0.73$ olarak bulunmuştur.

\section{Bulgular ve Yorum}

Araştırmada 5. sınıf Türkçe ders kitabındaki 8 temadan 29 metin ve 11 şiir toplam 2173 cümle üzerinde analiz gerçekleştirilmiştir. Kategorilere, özel alt alanlara ve cümlenin içerdiği anlama (pozitif, negatif, müphem, karışı) göre yüzdeler toplam cümle sayısı temel alınarak hesaplanmıştır. Bu cümlelerin \%5.75'i Vatanseverlik, \%4.74'ü Duyarlılık, \%2.07'si Sorumluluk, \%2.53'ü Sevgi, \%1.38'i Sağlık, \%2.99'u Bilimsellik, \%0.69'u Bağımsızlık, \%2.30'u Çalışkanl1k, \%1.66's1 Sayg1, \%1.43'ü Estetik, \%4.74'ü Denetim, \%0.14'ü Dinsellik, \%4.28'i Yaratıcılık, $\% 4.56$ 's1 Bilimsel Bilgi ve \%2.76's1 Eğlence değerini içermektedir. Toplam cümle sayısının $\% 57.75$ 'i ele alınan kategorilerde değerlendirilemeyen dolgu cümlesi olarak adlandırılan cümlelerdir.

Duygusal yön analizi sonuçlarına göre her bir kategoride en fazla değinilen özel alt alanlara ilişkin tablolar aşağıda sunulmuştur.

Tablo 1. Cümlelerde Vatanseverlik ile İlgili En Fazla Değinilen Özel Alt Alanlar

\begin{tabular}{|c|l|c|c|c|c|c|}
\hline Sıra & Özel Alt Alan & Cümle Sayısı & Pozitif & Negatif & Karışık & Müphem \\
\hline 1 & Türkçe’ye Önem & 58 & 33 & 20 & 2 & 3 \\
\hline 2 & Milli Birlik ve Beraberlik & 23 & 19 & - & 4 & - \\
\hline 3 & Milli Kültür & 21 & 17 & 1 & 2 & 1 \\
\hline 4 & Vatan-Millet Sevgisi & 17 & 13 & 2 & - & 2 \\
\hline 5 & Çağdaşlık & 5 & 2 & 3 & - & - \\
\hline 6 & Bayramlar & 1 & 1 & - & - & - \\
\hline
\end{tabular}

Tablo 1'e göre vatanseverlik alanı ile ilgili alt kategorilere ilişkin cümle sayıları göz önüne alındığında, ilk üç sırada Türkçe'ye önem, milli birlik ve beraberlik ve milli kültürün yer aldığı görülmektedir. İlk üç alt alanın hepsi pozitif cümleler ağırlıklıdır. Bayramlar ise en son sırada yer almıştır. Vatanseverlikle ilgili cümlelerin \%68.00'ı pozitif, \%20.8'i negatif, \%6.4'ü karışık, \%4.8’i müphem yöndeki cümlelerdir. 
Tablo 2. Cümlelerde Duyarlılık ile İlgili En Fazla Değinilen Özel Alt Alanlar

\begin{tabular}{|c|l|c|c|c|c|c|}
\hline Sıra & Özel Alt Alan & Cümle Sayısı & Pozitif & Negatif & Karışı & Müphem \\
\hline 1 & Dayanışma & 31 & 24 & 1 & 1 & 5 \\
\hline 2 & Toplumsal Duyarlılık & 22 & 18 & 3 & - & 1 \\
\hline 3 & Yardımseverlik & 15 & 12 & 1 & 1 & 1 \\
\hline 4 & Nezaket & 13 & 11 & - & - & 1 \\
\hline 5 & Hatasını Kabullenme & 8 & 4 & 2 & 1 & 1 \\
\hline 5 & Empati Kurma & 8 & 6 & 1 & - & 1 \\
\hline 6 & Doğal Çevreye Duyarlılık & 7 & 6 & 1 & - & - \\
\hline
\end{tabular}

Tablo 2’ye göre Türkçe’ye önem değeri 'Atatürk ve Türk Dili’ metninde, “Türk Dili dünyada en güzel, en zengin ve en kolay olan dillerden biridir", "Bir de Türk Dili, Türk Milleti için kutsal bir hazinedir" ifadeleri ile pozitif yönde aktarılmıştır. Çağdaşlık değeri 'Güneş'in Doğduğu Her Yer” metninde "Osmanl zamanında üç yüz yılda bir çăg değişiyormuş” ifadesi ile negatif yönde aktarılmıştır.

Cümle sayılarına göre alt alanlar incelendiğinde dayanışma ilk sıradadır. Onu, toplumsal duyarlılık ve yardımseverlik izlemektedir. En düşük cümle sayısına sahip alt alan ise doğal çevreye duyarlılıktır. Duyarlılık alanında pozitif cümleler ağırlıktadır. Duyarlılık ile ilgili cümlelerin \%78.64'ü pozitif, \%8.74'ü negatif, \%2.91'i karışık, \%9.71'i müphem yöndeki cümlelerdir.

Toplumsal duyarlılık değeri 'Şeker Dede' metninde "yoluna devam edecekti ki kendileriyle birlikte bekleyen görme engelli dedeyi hatırladı" ifadesi ile müphem yönde aktarılmıştır. Yardımseverlik değeri yine aynı metinde "gözleri görmeyen adamı elinden tutup karşıya geçirecekti ki ...” ifadesi ile pozitif yönde aktarılmıştır.

Tablo 3. Cümlelerde Sorumluluk ile İlgili En Fazla Değinilen Özel Alt Alanlar

\begin{tabular}{|c|l|c|c|c|c|c|}
\hline Sıra & Özel Alt Alan & Cümle Sayısı & Pozitif & Negatif & Karışık & Müphem \\
\hline 3 & $\begin{array}{l}\text { Üzerine Düşen Görevi Yerine } \\
\text { Getirme }\end{array}$ & 41 & 29 & 6 & 2 & 4 \\
\hline 2 & Tutumlu Olma & 2 & 1 & - & - & 1 \\
\hline 1 & $\begin{array}{l}\text { Vatandaş Hak ve Sorumlu- } \\
\text { luklarını Yerine Getirme }\end{array}$ & 1 & 1 & - & - & - \\
\hline 4 & Disiplinli Olma & 1 & 1 & - & - & - \\
\hline
\end{tabular}

Tablo 3'e göre sorumluluk alanında, üç alt alanın cümle sayılarının düşük olduğu görülmektedir. Üzerine düşen görevi yapma alt alanı ise ciddi farkla ilk sırada yer almaktadır. Alanda pozitif cümleler ağırlıklıdır. Sorumluluk ile ilgili cümlelerin \%71.11'i pozitif, \%13.33'ü negatif, \%4.44’ü karışık, \%11.11’i müphem yöndeki cümlelerdir.

Üzerine Düşen Görevi Yerine Getirme değeri ‘Çöp Ev’ metninde “öylece ertesi gün araştırmaya başlamak üzere derslerimize geri döndük" ifadesi ile pozitif yönde aktarılmıştır. Üzerine Düşen Görevi yerine getirme değeri aynı parçada "Yeniden ödevime dönerek bu konuyu unutmaya, geçiştirmeye çalıştım ama Pınar hiç rahat bırakmıyordu" ifadesi ile karışık yönde aktarılmıştır. 
Tablo 4. Cümlelerde Sevgi ile İlgili En Fazla Değinilen Özel Alt Alanlar

\begin{tabular}{|c|c|c|c|c|c|c|}
\hline Sıra & Özel Alt Alan & Cümle Sayısı & Pozitif & Negatif & Karışık & Müphem \\
\hline 1 & Doğa Sevgisi & 31 & 23 & 2 & 1 & 5 \\
\hline 2 & Aile Sevgisi & 24 & 19 & 1 & 1 & 3 \\
\hline
\end{tabular}

Tablo 4'e göre sevgi alanında, doğa sevgisi ve aile sevgisi alt alanları öne çıkmaktadır. Her iki alt alanın da cümle sayılarının diğer alanların alt alanlarına göre de oldukça göre yüksek olduğu görülmektedir. Sevgi ile ilgili cümlelerin \%76.36's1 pozitif, \%5.45'i negatif, \%3.64'ü karışık, \%14.55'i müphem yöndeki cümlelerdir. Pozitif cümleler ağırlıktadır. Parlakyıldız (2009) 5. Sınıf Türkçe ders kitabı üzerinde yaptığı çalışmasında 4 ders kitabını incelemiş ve sadece birinde "aile sevgisi" kavramına rastlamıştır.

Aile sevgisi değeri 'Küçük Kart Tanesi' metninde "Çocukların yüzlerinde, anne ve babalarıyla birlikte oyun oynamanın mutluluğunu, gözlerindeki o lşılttyı fark etti küçük kar tanesi" ifadesi ise pozitif yönde aktarılmıştır. Doğa Sevgisi ise, "Her yanı ormanlarla kaplı olan gölün çevresindeki ăgaçlar hoş kokuları ile buraya başka bir güzellik katıyor" ifadesi ile pozitif şekilde "Dört Mevsimde Dört Güzellik Abant” metninde kendine yer bulmuştur.

Tablo 5. Cümlelerde Sağlık ile İlgili En Fazla Değinilen Özel Alt Alanlar

\begin{tabular}{|c|c|c|c|c|c|c|}
\hline Sıra & Özel Alt Alan & Cümle Sayısı & Pozitif & Negatif & Karışık & Müphem \\
\hline 1 & Beslenmeye Önem & 27 & 14 & 8 & 3 & 2 \\
\hline 2 & Temiz Olmaya Önem & 3 & - & 3 & - & - \\
\hline
\end{tabular}

Tablo 5'e göre sağlık alanı ile ilgili alt alanlar incelendiğinde, beslenmeye önemin ilk sirada olduğu görülmektedir. Temiz olmaya önem ise tamamı negatif olan cümleleriyle son sıradadır. Sağlık ile ilgili cümlelerin \%46.67'si pozitif, \%36.67'si negatif, \%10.00'1 karış1k, \%6.67'si müphem yöndeki cümlelerdir.

Temiz olmaya önem değeri 'Çöp Ev' metninde “...evde biriktirilen ne varsa üzerime üzerime geliyordu” ifadeleri ile negatif yönde aktarılmıştır. Beslenmeye önem değeri 'Yeterli ve Dengeli Beslenme Nedir?' metninde “gereğinden fazla besin maddesi tüketilirse çok alınan bazı besinler vücutta yă̆ olarak depolandığından sağlık için zararlı olur” ifadesi ile negatif yönde aktarılmıştır.

Tablo 6. Cümlelerde Bilimsellik ile İlgili En Fazla Değinilen Özel Alt Alanlar

\begin{tabular}{|c|l|c|c|c|c|c|}
\hline Sıra & Özel Alt Alan & Cümle Sayısı & Pozitif & Negatif & Karışık & Müphem \\
\hline 1 & $\begin{array}{l}\text { Olaya Çok yönlü } \\
\text { Bakabilme }\end{array}$ & 21 & 9 & 10 & - & 2 \\
\hline 2 & Bilimsel Düşünme & 14 & 12 & 1 & - & 1 \\
\hline 2 & Bilginlere Değer Verme & 14 & 12 & 1 & - & 1 \\
\hline 3 & $\begin{array}{l}\text { Gerçekle Bağlantılı } \\
\text { Davranma }\end{array}$ & 9 & 7 & 1 & 1 & - \\
\hline 4 & Evrensellik & 6 & 6 & - & - & - \\
\hline 5 & Problem Çözme & 1 & - & - & 1 & - \\
\hline
\end{tabular}

Tablo 6'ya göre bilimsellik alanı incelendiğinde, olaya çok yönlü bakabilme ilk sırada yer alırken, bilimsel düşünme ve bilginlere değer verme ikinci sırayı paylaşmaktadır. Olaya çok 
yönlü bakabilmede cümleler negatif ağıllıklıyken, ikinci sırada olan alt alanlarda pozitif ağırlıklıdır. Problem çözme ise karışık olan tek cümleyle son sırada yer almaktadır. Bilimsellik ile ilgili cümlelerin $\% 70.77$ 'si pozitif, $\% 20.00$ '1 negatif, $\% 3.08$ 'i karışık, $\% 6.15$ 'i müphem yöndeki cümlelerdir. Şen (2008) 6. sınıfta okutulan beş ders kitabını incelemiş, bilimselliğe yalnızca ikisinde rastladığı görülmüştür.

Bilimsel Düşünme değeri 'Bilgi Çağı' parçasında "Gerçek rehber olarak Bilgiyi seçmeliyiz” cümlesiyle pozitif yönde aktarılmıştır. Olaya çok yönlü bakabilme ise 'Şu Heykeller Bak' parçasında "Bu durumda sanatçı, heykelinin boşlukta kaplayacă̆ı yeri, önünü, arkasını, dokusunu iyi düşünmek zorunda" ifadesiyle müphem yönde aktarılmıştır.

Tablo 7. Cümlelerde Bağımsızlıkla İlgili En Fazla Değinilen Özel Alt Alanlar

\begin{tabular}{|c|l|c|c|c|c|c|}
\hline Sıra & Özel Alt Alan & Cümle Sayısı & Pozitif & Negatif & Karışı & Müphem \\
\hline 1 & Cumhuriyet & 6 & 6 & - & - & - \\
\hline 2 & Özgürlük & 4 & 4 & - & - & - \\
\hline 4 & Egemenlik & 3 & 3 & - & - & - \\
\hline 3 & Barış & 2 & 2 & - & - & - \\
\hline
\end{tabular}

Tablo 7’de cümle sayılarına göre; cumhuriyet, özgürlük, egemenlik ilk üç sırada yer alırken, barış son sıradadır. Her bir özel alt değer pozitif ifade şeklindedir.

Özgürlük altı alanı 'Bilgi Çağı' parçasında "Bilgi güneşi yurdun hür ufkunda durmalı" cümlesiyle pozitif yönde aktarılmıştır.

Tablo 8. Cümlelerde Çalışkanlıkla İlgili En Fazla Değinilen Özel Alt Alanlar

\begin{tabular}{|c|c|c|c|c|c|c|}
\hline Sıra & Özel Alt Alan & Cümle Sayısı & Pozitif & Negatif & Karışık & Müphem \\
\hline 1 & Çaba Harcama & 41 & 38 & 1 & 2 & - \\
\hline 2 & Zamanı Etkili Kullanma & 9 & 5 & - & 4 & - \\
\hline
\end{tabular}

Tablo 8'de cümle sayılarına göre çaba harcama ilk sırada yer almaktadır. Çaba harcama özel alt alanında cümlelerin çoğunluğu pozitif ifade şeklindedir. Zamanı etkili kullanma alt alanında ise pozitif ve karışık ifadeler şeklinde kullanılmıştır. Çalışkanlık ile ilgili cümlelerin \%86.00'1 pozitif, \%2.00’1 negatif, \%12.00’1 karışık yöndeki cümlelerdir.

Çaba Harcama değeri 'Dilim Dilim Güzel Dilim' parçasında "Çalışmamı bir an önce tamamlamak için sabırsızlanıyordum" cümlesiyle pozitif yönde aktarılmıştır. Zamanı etkili kullanma değeri ise 'Tekerlemeci Dayı' parçasında "İçine otobüste ve dayımlarda okumak için öykü kitabı ve bir roman koydum" ifadesi ile pozitif yönde aktarılmıştır.

Tablo 9. Cümlelerde Saygı ile İlgili En Fazla Değinilen Özel Alt Alanlar

\begin{tabular}{|c|l|c|c|c|c|c|}
\hline Sıra & Özel Alt Alan & Cümle Sayısı & Pozitif & Negatif & Karışık & Müphem \\
\hline 6 & $\begin{array}{l}\text { Türk Büyüklerine } \\
\text { Saygı }\end{array}$ & 16 & 14 & - & - & 2 \\
\hline 2 & Başkalarına Saygı & 10 & 3 & 6 & - & 1 \\
\hline 5 & Hoşgörü & 3 & - & - & - & - \\
\hline 3 & Özsaygı & 3 & 1 & 2 & - & - \\
\hline 1 & Farklılıklara Saygı & 2 & 1 & 1 & - & - \\
\hline 4 & Haklara Saygı & 2 & 2 & - & - & - \\
\hline
\end{tabular}


Tablo 9'da cümle sayılarına göre Türk büyüklerine saygı, başkalarına saygı ilk iki sırada yer almaktadır. Türk büyüklerine saygı cümlelerinin çoğunluğu pozitif ifade şeklinde kullanılırken başkalarına saygı içeren cümlelerin çoğunluğu negatif ifade şeklindedir. Farklılıklara saygı ve haklara saygı özel alt alanı ise cümle sayısına göre son iki sırada yer almaktadır. Saygı ile ilgili cümlelerin \%61.11'i pozitif, \%25.00'1 negatif, \%13.89'u müphem yöndeki cümlelerdir. Kılınç ve Tunçbilek (2012)'in 2010-2011 eğitim-öğretim y1lında kullanılmak üzere tavsiye edilen ilköğretim ikinci kademe 7. Sınıf Türkçe Ders Kitabı üzerinde, hak ve özgürlükler temasını incelediği çalışmasında, hoşgörüye 4, saygıya 7, özsaygıya 1, farklılıklara saygıya 2 kez rastlanmıştır.

Saygı değeri 'Kanatlı Bal Kutusu' parçasında “Kovan adı verilen evlerinde koloni hâlinde yaşayan arlar, karşıllkkl saygl, iş bölümü ve sosyal düzen içerisinde yaşar" cümlesi ile pozitif yönde aktarılmıştır.

Tablo 10. Cümlelerde Estetik ile İlgili En Fazla Değinilen Özel Alt Alanlar

\begin{tabular}{|c|c|c|c|c|c|c|}
\hline Sıra & Özel Alt Alan & Cümle Sayısı & Pozitif & Negatif & Karışık & Müphem \\
\hline 2 & Hoş Kavramı & 17 & 13 & 1 & - & 3 \\
\hline 1 & Güzel Kavramı & 14 & 11 & 1 & 1 & 1 \\
\hline
\end{tabular}

Tablo 10'da cümle sayılarına göre hoş kavramı ilk sırada yer almaktadır. Hoş kavramı ve güzel kavramı özel alt alanında cümlelerin çoğunluğu pozitif ifade şeklindedir. Estetik ile ilgili cümlelerin \%77.42'si pozitif, \%6.45'i negatif, \%3.23'ü karışık, \%12.90’ı müphem yöndeki cümlelerdir.

Estetik değeri 'Şu Heykellere Bak' parçasında “Bu nedenle bir merdivene baktnca etkilenmiyoruz ama bir merdiven heykeline bakınca güzel duygular hissedebiliyoruz" cümlesiyle pozitif yönde ifade edilmiştir.

Tablo 11. Cümlelerde Denetim ile İlgili En Fazla Değinilen Özel Alt Alanlar

\begin{tabular}{|c|l|c|c|c|c|c|}
\hline Sıra & Özel Alt Alan & Cümle Sayısı & Pozitif & Negatif & Karışık & Müphem \\
\hline 4 & $\begin{array}{l}\text { Teşvik ve Ödüllendirme, } \\
\text { Cesaretlendirme-Yüreklendirme }\end{array}$ & 47 & 43 & - & 1 & 3 \\
\hline 2 & Kendine Güven & 22 & 14 & 4 & 1 & 3 \\
\hline 3 & Azimli Davranma & 14 & 7 & 1 & 3 & 3 \\
\hline 6 & Sabretme/Sabırlı Olma & 10 & 1 & 2 & 3 & 4 \\
\hline 1 & Aşırı Koruyucu Davranma & 8 & 5 & - & 1 & 2 \\
\hline 5 & Tasarruf & 2 & 2 & - & - & - \\
\hline
\end{tabular}

Tablo 11'de cümle sayısına göre Teşvik ve Ödüllendirme, Cesaretlendirme-Yüreklendirme, kendine güven ve azimli davranma ilk üç sırada yer almaktadır. Teşvik ve Ödüllendirme, Cesaretlendirme-Yüreklendirme, kendine güven ve azimli davranma alt alanlarındaki cümlelerin çoğunluğu pozitif ifade şeklindedir. Sabretme/sabırlı davranma, aşırı koruyucu davranma, tasarruf özel alt alanları ise son üç sırada yer almaktadır. Bu özel alt alanlardan sabretme/sabırlı olma alt alanındaki cümleler genellikle müphem ve karışık ifade şeklindedir. Denetim ile ilgili cümlelerin \%69.90'ı'sı pozitif, \%6.80'i negatif, \%8.74'ü karışık, \%14.56'sı müphem yöndeki cümlelerdir.

'Ay’da Bir Küçük Serçe' adlı metinde azimli davranma alt alanı "Küçük serçe bu, hiç pes eder mi, vazgeçer mi hayallerinden?” ifadesi ile pozitif yönde aktarılmıştır. 
Tablo 12. Cümlelerde Dinsellik ile İlgili En Fazla Değinilen Özel Alt Alanlar

\begin{tabular}{|c|c|c|c|c|c|c|}
\hline Sıra & Özel Alt Alan & Cümle Sayısı & Pozitif & Negatif & Karışıı & Müphem \\
\hline 1 & İbadete Teşvik & 3 & 3 & - & - & - \\
\hline
\end{tabular}

Tablo 12'ye göre ibadete teşvik özel alt alanı pozitif ifade şeklinde verilmiştir. Yaman vd. (2009), türkçe ders kitaplarında yer alan değerler üzerine yaptığı çalışmalarında, dini değerlerin son sıralarda yer aldığını belirtmiştir.

Dinsellik değeri “Ama padişahın için bir cami yapmayı düşündün mü hiç?” cümlesi ile pozitif yönde ifade edilmiş̧ir.

Tablo 13. Cümlelerde Yaratıcılık ile İlgili En Fazla Değinilen Özel Alt Alanlar

\begin{tabular}{|c|l|c|c|c|c|c|}
\hline Sıra & Özel Alt Alan & Cümle Sayısı & Pozitif & Negatif & Karışık & Müphem \\
\hline 2 & Tasarlama & 33 & 27 & 2 & 1 & 3 \\
\hline 3 & Merak & 32 & 12 & 1 & 1 & 18 \\
\hline 1 & Keşfetme & 28 & 16 & 2 & - & 10 \\
\hline
\end{tabular}

Tablo 13'te cümle sayısına göre tasarlama ilk sırada yer almaktadır ve pozitif ifade şeklinde verilmektedir. Merak alt alanında ise cümleler çoğunlukla müphem şeklinde ifade edilmiştir. Keşfetme alt alanında ise ifadeler pozitif şekilde ifade edilmiştir. Yaratıcılık ile ilgili cümlelerin \%59.14'ü pozitif, \%5.38'i negatif, \%2.15'i karış1k, \%33.33'ü müphem yöndeki cümlelerdir.

'Ay’da Bir Küçük Serçe' adlı metinde, tasarlama alt alanı "Gün boyunca düşler kurdu, planlar yaptı" ifadesiyle pozitif olarak aktarılmıştır. Merak alt boyutu ise, "Yeryüzünü ve insanları çok merak ediyordu" ifadesiyle müphem şekilde "Küçük Kar Tanesi”" adlı metinde yer almıştır.

Tablo 14. Cümlelerde Bilimsel Bilgi ile İlgili En Fazla Değinilen Özel Alt Alanlar

\begin{tabular}{|c|c|c|c|c|c|c|}
\hline Sıra & Özel Alt Alan & Cümle Sayısı & Pozitif & Negatif & Karışıı & Müphem \\
\hline 1 & Bilimsel Bilgi & 99 & 45 & 13 & 1 & 40 \\
\hline
\end{tabular}

Tablo 14'e göre bilimsel bilgi ile ilgili cümlelerin \%45.45’i pozitif, \%13.13’ü negatif, \%1.01’i karışık, \%40.40’1 müphem yöndeki cümlelerdir.

'Uzayda Yaşam' adlı metinde "Kaslar kaldıracakları fazla bir yük olmadiğı için kemiklere fazla baskı uygulamaz" ifadesi ile müphem olarak yer almıştır. Yine aynı metinde bilimsel bilgi "Sağlıklı kalabilmek için günde yaklaşık iki saat egzersiz yapmaları gerekir" ifadesiyle pozitif olarak verilmiştir. "Ünlü Fizikçi Albert Einstein, bu buluşun 10 yll önce kendisinin öne sürdüğü ama bilim dünyası tarafından destek bulamamıs kuramını doğruladığını görür" ifadesi de 'Uzay Teleskopu ve Edwin Powell Hubble” başlıklı metinde pozitif olarak yer almıştır.

Tablo 15. Cümlelerde Eğlence ile İlgili En Fazla Değinilen Özel Alt Alanlar

\begin{tabular}{|c|c|c|c|c|c|c|}
\hline Sıra & Özel Alt Alan & Cümle Sayısı & Pozitif & Negatif & Karışık & Müphem \\
\hline 2 & $\begin{array}{c}\text { Mutluluk, Sevinç, Zevk } \\
\text { Alma }\end{array}$ & 45 & 35 & 3 & 3 & 4 \\
\hline 1 & Oyunun Eğlendiriciliği & 15 & 5 & 2 & 1 & 7 \\
\hline
\end{tabular}

Tablo 15’e göre mutluluk, svinç, zevk alma özel alt alanı cümle sayısına göre ilk sırayı alırken, cümleler çoğunlukla pozitif şekilde ifade edilmektedir. Oyunun eğlendiriciliği alt alanında ise 
cümleler çoğunlukla müphem ifade şeklindedir. Eğlence ile ilgili cümlelerin \%66.67'si pozitif, \%8.33'ü negatif, \%6.67'si karış1k, \%18.33'ü müphem yöndeki cümlelerdir.

'Küçük Kar Tanesi' adlı metinde "Küçük kar tanesi ne kadar da neşeli ve mutluydu”, "Onu hiçbir şey bu kadar mutlu edemezdi" ifadelerin ile pozitif yönde "mutluluk, sevinç, zevk alma" alt alanında yer aldığı görülmektedir.

\section{Sonuç}

Bu araştırmada 5. sınıf Türkçe ders kitabında yer alan 8 temayı oluşturan 40 metinde yer alan 2173 cümle incelenmiştir. Yüzdeler esas alındığında metinlerde ele alınan değer kategorilerinin içerisinde ele alınan 2173 cümlede vatanseverlik değerini içeren cümlelerin birinci sırada olduğu, bunu sırasıyla denetim ve duyarlılık, bilimsel bilgi, yaratıcılık, bilimsellik, eğlence, sevgi, çalışkanlık, sorumluluk, saygı, estetik, sağlık, bağımsızlık ve dinsellik değerini içeren cümlelerin izlediği görülmektedir. Şen $(2008,763) 6$. sınıf Türkçe ders kitaplarını üzerine yaptığ1 çalışmasında, 5 farklı ders kitabını değerler açısından incelemiştir. Değerler frekanslarına göre sıralandığında, dört tane kitapta sevgi ilk sırada yer alırken vatanseverlik ikinci sırada, bir tanesinde ise vatanseverlik ilk sıra yer almıştır.

Duygusal yön analizi sonuçlarına göre ele alınan 15 kategoride de pozitif cümlelerin çoğunlukta olduğu saptanmıştır. Sağlık, sorumluluk, saygı, vatanseverlik, bilimsellik kategorilerinde negatif mesaj veren cümleler ikinci derecede ağırlık taşımaktadır. Vatanseverlik, çalışkanlık, duyarlılık, sorumluluk, sevgi, sağlık, bilimsellik, estetik, denetim, yaratıcılık ve eğlence kategorilerinde karışık ifadeler yer almaktadır. Bu durum metinlerdeki bu kategorilere ilişkin mesajların çok net olmadığını düşündürmektedir. Bu belirsizlik özellikle vatanseverlik kategorisinde milli kültür, Türkçe'ye önem ve milli birlik ve beraberlik, duyarlılık kategorisinde hatasını kabullenme, yardımseverlik ve dayanışma, sorumluluk kategorisinde üzerini düşen görevi yerine getirme, sevgi kategorisinde doğa sevgisi ve aile sevgisi, sağl1k kategorisinde beslenmeye önem, bilimsellik kategorisinde problem çözme ve gerçekle bağlantılı davranma, çalışkanlık kategorisinde çaba harcama ve zamanı etkili kullanma, estetik kategorisinde güzel kavramı, denetim kategorisinde aşırı koruyucu davranma, kendine güven, azimli davranma, teşvik ve ödüllendirme, cesaretlendirme-yüreklendirme, sabretme/sabırlı olma, yaratıcılık kategorisinde, eğlence kategorisinde oyunun eğlendiriciliği, mutluluk, sevinç, zevk alma özel alt alanlarındadır. 


\section{KAYNAKÇA}

Akdeniz, A., R., Karamustafaoğlu, M., \& Tekin, S. (2011). "Konu Alanı Ders Müfredatı Dersinin Yürütülmesi”. X. Ulusal Eğitim Bilimleri Kongresi, Abant İzzet Baysal Üniversitesi, Bolu.

Aydın, Z. (2004). Ailede Çocuğun Ahlak Eğitimi. İstanbul: DEM Yayınları.

Bacanlı, H. (1999). Duyuşsal Davranış Eğitimi. Ankara: Nobel Yayın Dağıtım.

Baymur, F. (1996). Genel Psikoloji. İstanbul: İnk1lap Kitapevi.

Bilgin, N. (1995). Sosyal Psikolojide Yöntem ve Pratik Çalışmalar. İstanbul: SistemYayıncılık.

Büyüköztürk, Ş., Çakmak, E., K., Akgün, Ö., E., Karadeniz, Ş., \& Demirel, F. (2011). Bilimsel Araştırma Yöntemleri. Ankara: Pegem Akademi Yayınları.

Demirel, Ö. (1996). Türkçe Programı ve Öğretimi. Ankara: Usem Yayınları, Ankara.

Erden, A. (2003). Klsa Öykü ve Dilbilimsel Eleştiri. İstanbul: Gendaş Kültür Yayınları.

Gökçe, O. (2006). İ̧̧erik Analizi: Kuramsal ve Pratik Bilgiler. Ankara: Siyasal Kitabevi.

Fayda, M. (2005). Karakter Eğitimi. İstanbul: Kubbealtı Neşriyat.

Güngör, E. (1993). Değerler Psikolojisi. Amsterdam: Hollanda Turk Akademisyenler Birliği Vakfi Yayınları.

Harris, E. L. (1991). Identifying Integrated Values Education Approaches in Secondary Schools. Yayımlanmamış Doktora Tezi, Office of Graduate Studies of Texas A \& M University, Texas, USA.

Kavcar, C. (1999). Edebiyat ve Eğitim. Ankara: Engin Yayınları.

Kılıç, A., \& Seven, S. (2002). Konu Alanı Ders Kitabı İncelemesi. Ankara: Pegem A Yayınları.

Kılınç, A., \& Tunçbilek G. (2012). "Türkçe Ders Kitaplarındaki "Hak ve Özgürlükler" Temasının Demokrasi Eğitimi Açısından İncelenmesi”. Mustafa Kemal Üniversitesi Sosyal Bilimler Enstitüsü Dergisi, Cilt 9, Sayı 17, 259- 270.

Krippendorff, K. (2004). Content Analysis: An Introduction to Its Methodology. USA: Sage Publications. Küçükahmet, L. (2003). Konu Alanı Ders Kitabı İnceleme Kılavuzu. Ankara: Nobel Yayın Dağıtım.

Lazerson, M., Mclaughlin, J., B., Mcpherson, B., \& Bailey, S., K. (1985). An Education of Value: The Purposes and Practices of Schools. New York: Cambridge University Press.

Lovat, T. J., \& Clement, N. D. (2008). "The Pedagogical Imperative of Values Education”. Journal of Beliefs \& Values, 29 (3), 273-285.

MEB (2013). Ortä̈ğretim Türkçe Dersi Öğretim Programı (5. 6. 7. 8. Sınıflar). Ankara: MEB Yayınları.

Parlakyıldız, H. (2009). “ïlkokul İkinci Devrede Türkçe Ders Kitaplarındaki Moral Değerlere Kısa Bir Bakış” (1948-1968 Yı1ları Arası). Uludağ Üniversitesi Eğitim Fakültesi Dergisi, XXII (1).

Sağnak, M. (2007). "Ortaöğretim Okullarında Öğrenim Gören Öğrencilerin Okulun Örgütsel Değerlerine İlişkin Algıları ile Kişisel Değerleri Arasındaki Uyum”. Eds. Kaymakcan, R., Kenan, S., Hokelekli, H., Arslan, Ş., \& Zengin, M. Değerler ve Eğitimi Uluslararası Sempozyumu, 715-726. İstanbul: Değerler Eğitimi Merkezi Yayınları.

Şen, Ü. (2008). "Altıncı Sınıf Türkçe Ders Kitaplarındaki Metinlerin İlettiği Değerler Açısından İncelenmesi”. Uluslararası Sosyal Araştırmalar Dergisi, Sayı 1, Cilt 5, 763.

Tural, S. (1992). Kültürel Kimlik Üzerine Düşünceler. Ankara: Ecdad Yayınevi.

Tavşancıl, E., \& Aslan, E. (2001). Sözel, Yazılı ve Diğer Materyaller İçin İçerik Analizi ve Uygulama Örnekleri. İstanbul: Epsilon Yayınları.

Ulu Kalın, Ö., \& Topkaya, Y. (2009). "9. Sınıf Coğrafya Ders Kitabının Okunabilirliği ve Hedef Yaş Düzeyine Uygunluğu”. 1. Uluslararası Türkiye Eğitim Araştırmaları Kongresi. 18 Mart Üniversitesi, Çanakkale.

Ünlüer, G., \& Yaşar, Ş. (2012). "Sosyal Bilgiler Dersinde Gazete Kullanımına İlişkin Öğrenci Görüşleri”. Eskişehir Osmangazi Üniversitesi Sosyal Bilimler Dergisi, 13 (1), $43-57$.

Yaman H., Taflan S., \& Çolak S. (2009). Değerler Eğitimi Dergisi. Cilt 7, No: 18. 
